\title{
Revaluation of Fixed Assets Before IPO: A Study on Textile Industry in Bangladesh
}

\author{
Md. Tahidur Rahman \\ Department of Business Administration, EXIM Bank Agricultural University Bangladesh, Chapainawabganj, Bangladesh \\ Email Address: \\ towhidais@gmail.com

\section{To cite this article:} \\ Md. Tahidur Rahman. Revaluation of Fixed Assets Before IPO: A Study on Textile Industry in Bangladesh. Journal of Finance and \\ Accounting. Vol. 5, No. 5, 2017, pp. 200-205. doi: 10.11648/j.jfa.20170505.14
}

Received: September 12, 2017; Accepted: September 23, 2017; Published: November 2, 2017

\begin{abstract}
The textile and clothing sector of Bangladesh contributes more than 81 percent of foreign exchange earnings of the country. Considering the number of companies listed on the Dhaka Stock Exchange (DSE), textile was the second largest sector having 44 companies after insurance. Around fifty percent companies of the sector became listed on the DSE through Initial Public Offerings (IPO) during the period of January 2010 to March 2016. The study, based on prospectus data, intended to explore the practice of pre-IPO revaluation of fixed assets by textile industry in Bangladesh. Related objective of this study was to find out the factor(s) that influence(s) the growth of revaluation amount. Among the years under study, the highest number of textile companies became listed on DSE during 2014 and 2015 that accounted for about 55 percent growth of the sector. In the midst of controversies and doubts about the application and fairness of asset revaluation practice, a large number of textile companies in Bangladesh have been found revaluing their fixed asset as an option outlined in IAS 16. Thanks to the revaluation of fixed asset, average Net Asset Value (NAV) of textile companies raised from BDT 16.95 per share to BDT 28.54 per share with an increase of 68.38 percent. The study has observed an average increase in the value of fixed assets by 42 percent with a minimum of 4 percent and a maximum of 130 percent. Intensity of fixed assets has been found to have significant negative influence on the growth of fixed assets. This implies that textile companies which have low percentage of fixed assets on total asset observed hefty growth of fixed asset after revaluation. It is expected that the outcomes of the study will be useful to regulators, investors, financial analysts, and academics. Reporting of fixed assets in current market prices would assist investors and others make unbiased predictions about firms' future performance. However, the condition is that asset revaluation should be made with utmost fairness and transparency.
\end{abstract}

Keywords: Asset Revaluation, Textile Industry, IPO Companies in Bangladesh

\section{Introduction}

The practice of increasing or decreasing the carrying value of fixed assets in case of any major changes in their fair market value is known as revaluation of fixed assets. It is the restatement of an asset's book value to its approximate current value [1]. Current values of assets are more relevant to financial statement users [2]. Asset revaluation, if it is properly done, helps attain: fair 'value information' for stakeholders, reduction of information asymmetry, minimization of opportunistic behavior, and more accurate investment decision [3]. Fixed asset revaluations are common practice in some developed countries like Australia, New Zealand, the United Kingdom, the Netherlands, Belgium, France, Spain, and Italy [4]. In contrast, it is not allowed in some other developed countries like United States, Germany, and Japan [5].

In Bangladesh, asset revaluation has been practicing since the adoption of 'International Accounting Standard (IAS) 16: Property, Plant and Equipment' as 'Bangladesh Accounting Standard (BAS) 16: Property, Plant and Equipment' in January 2007. IAS 16:15 requires that an item of Property, Plant and Equipment (PPE) that qualifies for recognition as an asset shall be shown at its cost in the books of accounts, which is the cash price equivalent at the recognition date [6]. After initial recognition, companies are permitted to make choice between two valuation models - cost model, and revaluation model as their accounting policy and shall apply that policy to an entire class of PPE [6]. Cost model assumes that an item shall be carried at its cost minus any 
accumulated depreciation and any accumulated impairment losses, while revaluation model requires that asset shall be carried at revalued amount minus any subsequent accumulated depreciation [6].

However, using the upward revaluation that increases the amount of shareholder equity, managers can lower company's debt-to-equity ratio, improve its capital structure and reduce debt costs. Furthermore, upward assets revaluations with increased amount of assets and equity can reduce profitability ratios such as return on equity or return on total asset. Thus, upward asset revaluation is widely believed to be the subject of managerial discretion because market values of fixed asset are normally unavailable and estimates are unverifiable [2].

The textile and clothing sector of Bangladesh, the largest contributor to the economy of the country, accounts for more than 81 percent of foreign exchange earnings in FY2013-2014 [7]. The sector provided 4.2 million direct jobs and 16 percent of GDP of the country during the same period [8]. From the view point of number of listed companies on the DSE, textile is the second largest sector having 44 companies after insurance sector that has 46 companies. Out of 44 textile companies 22 companies became listed on the DSE through Initial Public Offerings (IPO) during the last six years. Like all other countries of the world, companies in Bangladesh intend to be listed on the exchange are required to prepare and submit prospectus before the start of subscription fulfilling different mandatory and voluntary disclosure requirements. Subscribers' interest as well as the offer price of the shares intended to be sold through IPO largely depend on the accounting figures disclosed in the prospectus. In order for exhibiting the true and fair view of balance sheet figures, it is therefore, wise for the companies to revalue their fixed assets, if the carrying value of the assets become significantly lower than their market value. However, the choice between fair value and historical cost accounting has been the subject of long-standing controversy among the academics, managers, investors, standard setters, and regulators. It is often criticized that some companies revalue their fixed assets unfairly and illogically to fulfill their ill motives.

In the midst of controversies and doubts about the application and fairness of upward asset revaluation practice, a large number of IPO companies in Bangladesh are revaluing their fixed assets as an option outlined in IAS 16. In addition, the probe committee report on 'share market crush in 2010' led by Khondoker Ibrahim Khaled pointed asset revaluation as one of the reasons of the crush [9]. But no such extensive study has yet been undertaken to identify whether there was really any influence of asset revaluation behind the crush or whether revaluations were done fairly. In addition, the capital market of Bangladesh is different from the markets of developed countries and, therefore, the factors that influence asset revaluation in developed countries may not be applicable in Bangladesh. But most of the accounting researchers have not concentrated deeply or overlooked such an important and burning issue in Bangladesh. As of today, only few researchers have addressed asset revaluation issue in Bangladesh. Nonetheless, the market-based evidence on this subject is very limited in the country.

The existing vacuity requires a thorough investigation of the asset revaluation practices of newly listed textile companies especially the most growing textile industry in Bangladesh. Study on this field can explore the determinants of asset revaluation and provide certain contribution to the existing stock of knowledge. It is believed that the findings of the study will be of great help for regulators (BSEC, DSE, CSE, and ICAB) to outline their policies and to strengthen the capital market of Bangladesh.

Considering the aforesaid circumstances and the research gap the main objective of this study is to explore the practice of fixed assets revaluation before IPO by textile industry in Bangladesh. Related objective of this study is to find out the factor(s) that influence(s) the growth of revaluation amount. The remaining parts of the paper have been designed as follows: section 2 deals with review of related literature; section 3 describes the methodology; section 4 presents the empirical results; and section 5 contains conclusion and recommendations.

\section{Review of Literature}

Empirical studies on asset revaluation had been conducted in developed as well as developing economies covering mainly the issues like motivational factors behind asset revaluation, factors influencing assets revaluation, impact of revaluation on future performance, and so forth. In most of these researches multiple regressions have dominantly been applied to investigate the managers' motives for revaluation choice. They mainly assume manager's opportunistic behavior and have also found a number of factors that affect manager's decision for asset revalorization especially the upward revaluation.

Barac and Sodan [2] found managers as opportunistic who use asset revaluation as a device to improve perceptive borrowing capacity of their respective company, and consequently, to reduce debt cost. They also found that the companies which are large and profitable but had low liquidity ratio, low cash flow ratio, and increasing debt were more likely to perform upward revaluation. Herrmann, Saudagaran and Thomas [10] argue that historical cost is subject to less manipulation than fair values measures and is considered a more faithful way of representing fixed asset. Brown, Izan and Loh [1] found higher debt-to asset ratios, higher fixed asset intensity and lower tax-free reserves. Easton, Eddey and Harris [5], to investigate the motives behind asset revaluation, reported that the primary reason Australian managers revalue assets is to present true and fair financial statements. Their survey also indicates that the second most common motivation to asset revaluation decision is debt-to-equity ratios. Another Australian study conducted by Cotter and Zimmer [11] claimed the same as Barak and Sodan [2] that revaluers tended to experience a declining operating cash flow and increasing level of secured debt. Aboody, Barth and Kasznik [12] found that the UK 
firms used upward revaluation to signal their superior future operating performance. They found that upward revaluations of fixed assets by UK Firms were significantly positively related to changes in future performance, measured by operating income and cash flow from operations, indicating revaluations reflect asset value changes. Missonier-Piera [13] found a new variable that high export sales were associated with the use of upward asset revaluation. His findings suggest that revaluation is used as a device to improve the perceptions of creditors about the financial health of the firm and thereby improve the firm's borrowing capacity.

Cheng and Lin [14] studied timing issue unlike the existing studies on management motivation behind asset revaluation. They found that revaluers had high share return and industry leverage two years before the revaluation. These findings indicate that UK companies delay the recognition of increased asset values until this information has been confirmed by their superior market performance. They also found that that upward fixed asset revaluation decisions were used to reduce contracting costs, political costs and information asymmetry. The motive to reduce political cost reduction is also supported by the research of [4]. Their findings mean that larger firms are found to be more likely to revalue their assets in order to mitigate political costs. Iatardis and Kilirgiotis [15] in their study exposed that firm size was positively related to fixed asset revaluation which is identical to the finding of Seng and Su [6]. The study found some opposite view that firms with foreign operations, with low fixed assets, and with high debt capital needs are more likely to perform fixed asset revaluations. The study also shows that fixed asset revaluation is negatively related to earnings management.

In their study about choice of fair value versus historical cost accounting for non-financial assets Christensen and Nikolaev [16] found a very limited use of fair value accounting but the market force determine the choice. According to them, fair value accounting is used when reliable fair value estimates are available at a low cost and when they convey information about operating performance.

While exploring the experience of fixed asset revaluation in Indonesia, a developing third world country, Zakaria, et al. [3] investigated various motives underpinning the revaluation of fixed assets and the effects of using either a cost or revaluation model. A model has been used in the study that embraces seven motive factors and two revaluation effects factors. However, the study has failed to generalize the findings. Tabari and Adi [17] investigated factors affecting the decisions made by companies' management staff to perform the revaluation of fixed assets in Iran. The regression coefficients demonstrated a significant relationship between the revaluation of assets with the ratio of total debt (RTD), operating cash flow (OCF), and natural logarithm of total assets (NLTA) before performing the revaluation and changes in fixed assets (CFA) of the companies.

In Bangladesh only few articles have been found which are indirectly related to asset revaluation. The study of Razzaque, Rahman and Salat [18] was conducted in the textile sector and found asset revaluation practice in 35 percent of the sample companies in Bangladesh. Alam [19] pointed the 'faulty asset revaluation' as one of the reasons of '2010 stock market debacle' in Bangladesh. Similar to the Alam's study, Hasan, Rahman and Hossain [20] presented a case study where they merely mentioned the probe committee report led by Khondoker Ibrahim Khaled and also the comment of ICAB on asset revaluation but they did not go further investigation into whether the asset revaluation had truly any impact on 2010 share market crush in Bangladesh.

Moreover, previous researches identified the following factors and circumstances that affect the revaluation decision: issuance of bonus shares, takeover threats, tight lending agreement, increasing new debt, declining cash flow, growth prospects, existence of fixed assets which can be revalued, prior revaluation pattern, depletion of equity reserves, industry sector, indebtedness, liquidity, size, and foreign sales. Some of these factors have be included as variables in the current study to identify factors and circumstances that affect the revaluation decision of textile companies in Bangladesh.

\section{Methodology of the Study}

The study has been conducted based on the secondary sources of information. A lion's share of the data has been collected from the prospectus of sample companies. Remaining data have been extracted from the website of DSE and CSE. This research has included the textile companies that became listed on the DSE during January 2010 to March 2016. All the twenty two companies under textile industry that became listed during the period were taken into consideration for the study. The companies were classified into two categories: 'revaluers' and 'non-revaluers'. A revaluer has been defined as a company that revalued its assets prior to the issue of IPO prospectus. A company that did not perform revaluation prior to issue of IPO prospectus has been classified as a non-revaluer. Thus, sixteen companies were found that revalued their fixed assets during the period under study. Gathered data, for the purpose of accomplishing the objective, have been analyzed with the help of IBM SPSS Statistics 22 using the univariate, bivariate, and multivariate techniques where applicable.

\subsection{Description of the Variables and Development of the Hypothesis}

Growth of fixed asset (GFA) has been considered the only dependent variable of this study. GFA means the growth of fixed asset caused by revaluation decision. Consistent with prior researches and with respect to specificity of Bangladeshi companies, several factors that could affect growth of fixed asset through revaluation are: age of the company, level of indebtedness, cost of debt, cash flow ratios, liquidity, fixed asset intensity, size, return on equity, net asset value, and return on equity. The current study has considered four independent variables which are as follows: 


\subsubsection{Company Age (AGE)}

AGE of the company at revaluation date from the date of commercial operation may be a factor behind revaluation. It is assumed that old aged companies following the cost principles of accounting will produce high growth in revaluation amount and vice versa. Therefore, company age may have positive influence on growth of revaluation amount.

\subsubsection{Fixed Asset Intensity (FAI)}

FAI is calculated as long term assets divided by total assets before revaluation. It can affect company's revaluation amount positively [1]. Low ratio of fixed asset to total assets may be due to under valuation of the assets [15]. In this case, the growth of revaluation amount will be higher. On the other hand, if the fixed asset intensity is high, the effect of the revaluation may also be high. In this case the relation could be positive.

\subsubsection{Debt-Asset Ratio (DAR)}

DAR is calculated as total liability divided by total assets before revaluation. This ratio may have a positive influence on revaluation decision and ultimately the revaluation amount. Higher debt to asset ratio increases borrowing cost, therefore, managers may want to apply revaluation technique to reduce cost of borrowing $[1,2,14,17]$.

\subsubsection{Net Asset Value Per Share (NAV)}

NAV is calculated as the total shareholders' equity divided by the total number of equity shares outstanding before revaluation. This ratio is highly considered in setting IPO offer price as well as in making purchase decisions of primary shares. Managers may become interested to revalue their fixed assets for setting higher offer price. Therefore, it may be assumed that lower net asset value per share has higher influence on revaluation decision and the growth of revaluation amount as well.

\subsection{Model Set}

Considering the above dependent and independent variables the regression model of the study stood as:

$$
\mathrm{GFA}=\alpha+\beta \mathrm{AGE}+\beta \mathrm{FAI}+\beta \mathrm{DAR}+\beta \mathrm{NAV}+\mathrm{e}
$$

Where,

GFA $=$ Growth of fixed asset after revaluation;

AGE $=$ Company Age;

FAI = Fixed Assets Intensity;

DAR $=$ Debt-asset Ratio; and

$\mathrm{NAV}=$ Net Asset Value per Share.

\subsection{The Hypothesis}

Based on the discussion of above variables the only alternative hypothesis that has been drawn in the study is that growth of revaluation amount is strongly associated with company's age, fixed asset intensity, debt to asset ratio, and net asset value per share.

\section{Data Analysis and Discussion}

It has been evident from Table 1 that asset revaluation before IPO is very common in the textile industry of Bangladesh. On an average about 73 percent of the sample companies under study performed asset revaluation before IPO.

Table 1. Revaluation of Fixed Assets by Sample Companies.

\begin{tabular}{lll}
\hline Company Character & Frequency & Percent \\
\hline Revaluation Performed & 16 & 72.7 \\
Revaluation Not performed & 6 & 27.3 \\
Total- & 22 & 100.0 \\
\hline
\end{tabular}

Source: Developed by the researcher from collected data.

Table 2 shows a significant growth of textile companies listed on the DSE during the last six years. Out of the total 44 companies in the industry 22 companies became listed during the period and out of the 22 companies around 55 percent companies (12) became listed during 2014 and 2015.

Table 2. Listing of Textile Companies During the Study Period.

\begin{tabular}{lll}
\hline Year of Listing & Frequency & Percentage \\
\hline 2010 & 2 & 9.10 \\
2011 & 1 & 4.55 \\
2012 & 3 & 13.63 \\
2013 & 3 & 13.63 \\
2014 & 6 & 27.27 \\
2015 & 6 & 27.27 \\
2016 & 1 & 4.55 \\
Total & 22 & 100.00 \\
\hline
\end{tabular}

Source: Developed by the researcher from collected data.

Descriptive statistics of Table 3 shows that the average amount of money collected by each company under textile industry has been BDT 712.52 million with a minimum amount of BDT 200 million and a maximum of BDT 1261.70 million. The most significant thing that happened during the period under study was change in NAV. The average NAV without revaluation of fixed assets was BDT 16.95 per share which became BDT 28.54 per share after the revaluation of fixed assets with an increase of 68.38 percent. Another significant thing has been observed from the descriptive statistics is that revaluation of fixed assets was accounted for an average of 42 percent increase in the value of fixed assets with a minimum increase of 4 percent and a maximum change of 130 percent. From the view point of Earning Per Share (EPS), an average of 28 percent increase has been observed in the last year's financial statement disclosed in the IPO prospectus as compared to the EPS of one year before. 
Table 3. Descriptive Statistics of dependent, independent, and other variables.

\begin{tabular}{|c|c|c|c|c|}
\hline & Mini & Maxi & Mean & Std. Deviation \\
\hline AGE & 6.18 & 20.61 & 12.59 & 5.09 \\
\hline Offer price per share & 10.00 & 37.00 & 22.19 & 9.74 \\
\hline Collection of BDT $(\mathrm{mn})$ through IPO & 200.00 & 1261.70 & 712.52 & 356.88 \\
\hline Revaluation Amount in BDT (mn) & 30.57 & 1785.34 & 563.88 & 472.51 \\
\hline NAV Per Share (BDT) with revaluation & 15.11 & 42.14 & 28.54 & 9.02 \\
\hline NAV Per Share (BDT) without revaluation & 5.30 & 26.57 & 16.95 & 5.16 \\
\hline Latest EPS (BDT) in IPO Prospectus & .68 & 7.19 & 2.87 & 1.78 \\
\hline EPS(BDT) one year before the latest EPS & .06 & 5.41 & 2.23 & 1.54 \\
\hline Fixed Asset in BDT (mn) with Revaluation & 498.03 & 3923.34 & 1404.34 & 934.05 \\
\hline Total Assets in BDT (mn) with Revaluation & 848.68 & 5903.29 & 2527.96 & 1316.82 \\
\hline Total Equity in BDT (mn) with Revaluation & 563.36 & 3761.66 & 1567.16 & 859.07 \\
\hline Total Liability in BDT (mn) & 166.56 & 2141.63 & 960.80 & 578.99 \\
\hline Total Equity before Revaluation in BDT (mn) & 459.69 & 1976.32 & 1003.28 & 439.16 \\
\hline Total Assets before Revaluation in BDT (mn) & 818.11 & 4117.95 & 1964.08 & 893.85 \\
\hline Fixed Asset Before Revaluation in BDT (mn) & 428.79 & 2332.61 & 1400.20 & 557.17 \\
\hline Growth(\%) of Fixed Asset after revaluation & .04 & 1.30 & .42 & .35 \\
\hline Fixed Asset Intensity & .43 & .96 & .73 & .16 \\
\hline Debt to Asset Ratio & .19 & .73 & .46 & .16 \\
\hline
\end{tabular}

Source: Developed by the researcher from collected data.

The correlation among dependent and independent variables shown in Table 4 proves that there is a significant relationship between growth of fixed assets and fixed asset intensity at percent level of significance. The table also proves that there is no significant multicolliniarity problem among the variables.

Table 4. Pearson Correlations of Dependent and Independent Variables.

\begin{tabular}{lllllll}
\hline & & AGE & NAV & GFA & FAI & DAR \\
\hline \multirow{2}{*}{ AGE } & Pearson Correlation & 1 & .092 & .206 & .082 & -.085 \\
& Sig. (2-tailed) & & .736 & .444 & .764 & .753 \\
\multirow{2}{*}{ NAV } & Pearson Correlation & .092 & 1 & .153 & -.069 & -.023 \\
& Sig. (2-tailed) & .736 & & .572 & .800 & .934 \\
& Pearson Correlation & .206 & .153 & 1 & $-.569^{*}$ & -.112 \\
\multirow{2}{*}{ FAI } & Sig. (2-tailed) & .444 & .572 & & .021 & .680 \\
& Pearson Correlation & .082 & -.069 & $-.569^{*}$ & 1 & -.189 \\
\multirow{2}{*}{ DAR } & Sig. (2-tailed) & .764 & .800 & .021 & -483 \\
& Pearson Correlation & -.085 & -.023 & -.112 & -.189 & 1 \\
\hline
\end{tabular}

*. Correlation is significant at the 0.05 level (2-tailed).

Table 5. Test of Hypothesis.

Model Summary

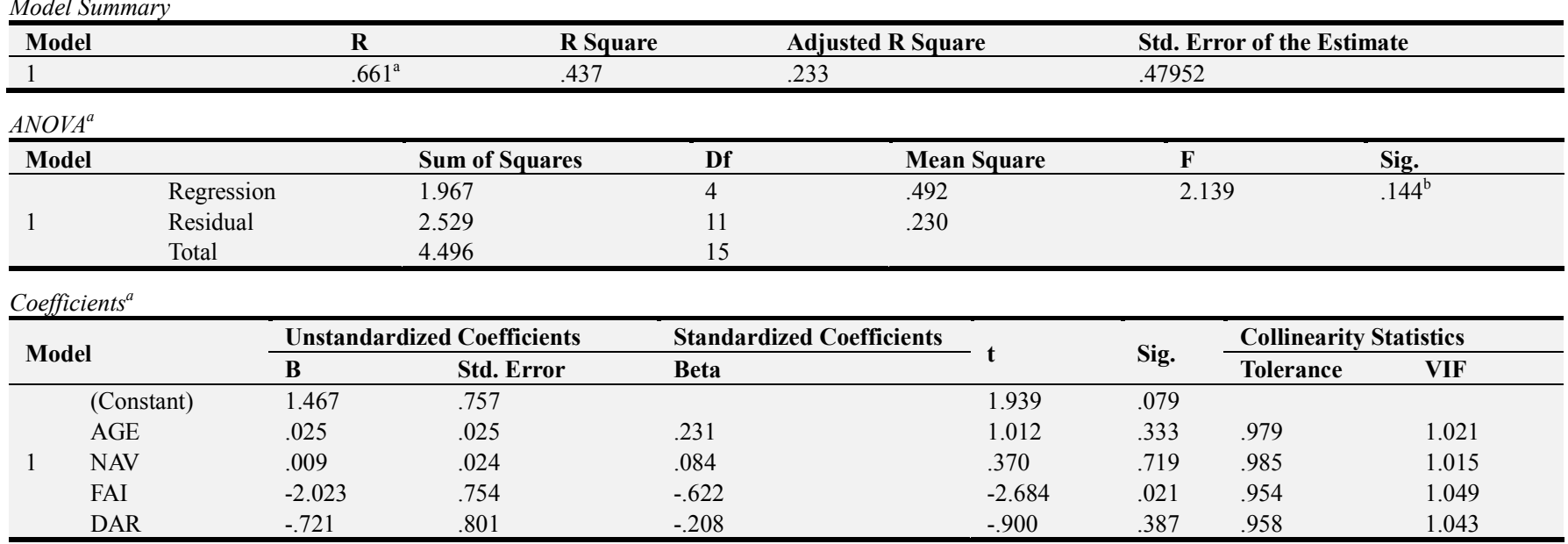

a. Dependent Variable: GFA

b. Predictors: (Constant), AGE, NAV, FAI, DAR 
The multiple regression analysis in Table 5 shows that AGE and NAV have positive influence whereas FAI and DAR have positive influence on the GFA. But the influence of FAI is significant at 5 percent level. Thus, rejecting the null hypothesis alternative hypothesis that growth of fixed asset amount is strongly associated with company's fixed asset intensity can be accepted. As the VIF of all the variables are around 1 , it can be assumed that there is no multicooliniarity problem among the variables.

\section{Conclusion}

Revaluation of fixed assets before IPO is a common practice in the textile industry of Bangladesh. On an average, the sample companies under textile industry category increased the value of their fixed assets by 42 percent with a minimum of 4 percent and a maximum of 130 percent. Among the years under study, 2014 and 2015 observed the highest number of newly listed textile companies in Bangladesh, the combined percentage of which was about 55 percent. Moreover, fixed assets intensity has been found to have negative influence on the growth of fixed assets. This implies that the textile companies which have low percentage of fixed assets on total asset observe hefty growth of fixed asset after revaluation. The main limitation of the study is that it covers only the textile industry only. The picture would have been different if other industry would have been incorporated. As the study focus on the factors that contribute to fixed asset revaluations, it is expected that the outcomes of the study will be useful for the regulators, investors and financial analysts, and academics. The reporting of asset values based on fair values would assist investors and others making unbiased predictions about firms' future performance. But the condition is utmost fairness and transparency should be ensured in the overall process of fixed asset revaluation.

\section{References}

[1] Brown, Philip, H. Y. Izan, and Alfred L. Loh. "Fixed Asset Revaluation and Managerial Incentives." ABACUS 28, no. 1 (1992): 36-57.

[2] Barac, Zeljana Aljinovic, and Slavko Sodan. "Motives for Asset Revaluatioin Policy Choice in Croatia." Croatian Operational Research Review (CRORR) 2 (2011): 60-70.

[3] Zakaria, Adam, David John Edwards, Gary David Holt, and Vijay Ramchandran. "A Review of Property, Plant and Equipment Asset Revaluation Decision Making in Indonesia: Development of a Conceptual Model." Mindanao Journal of Science and Technology 12 (2014): 109-28.

[4] Seng, Dyna, and Jiahua Su. "Asset Devaluations: The Motivation behind Management Decisions Evidence from New Zealand Firms." International Journal of Business Strategy 11, no. 2 (2011): 67-76.

[5] Easton, Peter D., Peter H. Eddey, and Treveo S. Harris. "An
Investigation of Revaluation of Tangible Long-lived Assets." Journal of accounting Research 31 (1993): 1-18.

[6] IASB. "International accounting standard No. 16: Property, Plant, and Equipment." International Accounting Standards Board, 2005.

[7] BGMEA. Story: BGMEA. 2016. http://www.bgmea.com.bd/blog/story/877 (accessed February 27, 2016).

[8] BKMEA. Knitware Industry: BKMEA. 2016 http://www.bkmea.com/History-of-Development-of-Knitwearof-Bangladesh.html (accessed February 27, 2016).

[9] Khaled, Khondokor Ibrahim. Share Market Inquiry Committee, 2011. Dhaka: Ministry of Finance, Government of the Peoples' Republic of Bangladesh, 2011, 139.

[10] Herrmann, Don, Shahrokh M. Saudagaran, and Wayne B. Thomas. "The Quality of Fair Value Measurement for Property, Plant and Equipment." Accounting Forum 30 (2005): 43-59.

[11] Cotter, Jullie, and Ian Zimmer. "Asset Revaluation and Assessment of Borrowing Capacity." ABACUS 31, no. 1 (1995): 136-151.

[12] Abody, David, Mary E. Barth, and Ron Kasznik. "Revaluation of Fixed Assets and Future Firm Performance: Evidence from the UK." Journal of Accounting and Economics 26 (1999): $147-71$.

[13] Missonier-Piera, Franck. "Motives for Fixed-asset Revaluation: An Empirical Analysis with Swiss Data." The Internatiional Journal of Accounting 42 (2007): 186-205.

[14] Cheng, C. S. Agens, and Stephen W. J. Lin. "When Do Firms Revalue Their Assets Upwards? Evidence from the UK." International Journal of Accounting and Information Management 17, no. 2 (1999): 166-88.

[15] Iatridis, George Emmanuel, and George Kilirgiotis. "Incentives for Fixed Asset Revaluations: The UK Evidence." Journal of Applied Accounting Research 13, no. 1 (2012): 5-20.

[16] Christensen, Hans B., and Valeri V. Nikolaev. "Does Fair Value Accounting for Non-financial Assets Pass the Market Test?" Rev Account Stud 18, no. 3 (2013): 734-75.

[17] Tabari, Naser Yadollahzadeh, and Marzieh Adi. "Factors Affecting the Decision to Revaluation of Assets in Listed Companies of Tehran Stock Exchange(TSE)." International Journal of Scientific Management and Development 2, no. 8 (2014): 373-77.

[18] Razzaque, Rushdi Md. Rezaur, Muhammad Zahedur Rahman, and Amirus Salat. "Earnings Management: An Analysis on Textile Sector of Bangladesh." The Cost and Management 34, no. 5 (September-October 2006): 5-13.

[19] Alam, Syed Golam Sirajul. "Recent Trends in Capital Market of Bangladesh: Critical Evaluation of Regulation." Asian Institute of Technology, 2012. 22.

[20] Hasan, Md Shamimul, Rashidah Abdul Rahman, and Syed Zabid Hossain. "Corporate Accruals Practices of Listed Companies in Bangladesh." European Journal of Economics and Management 1, no. 1 (2014): 17-46. 